\title{
ANALISIS STRUKTUR NARATIF MULABUKANING DAKWAH RASUL DALAM WAYANG KEKAYON KHALIFAH LAKON I
}

\author{
Lutfianto \\ SMAN1 Pajangan Bantul Yogyakarta \\ lootfie80@gmail.com
}

\begin{abstract}
Abstrak
Perjalanan dakwah rasul tidak hanya ada dalam sirah Nabawiyah, perjalanan dakwah rasul juga terdapat dalam cerita wayang. Wayang tersebut adalah Wayang Kekayon Khalifah. Dalam tulisan ini penulis akan menghadirkan teks lakon 1 Mulabukaning Dakwah Rasul. Selain itu penulis juga akan menganalisis teks tersebut dengan analisis naratif. Hal ini bertujuan untuk membantu pemahaman pembaca tentang Lakon Mulabukaning Dakwah Rasul.Hasil penelitian menunjukkan bahwa lakon Mulabukaning Dakwah Rasul terdiri dari tiga babak.Dari ketiga babak tersebut pembaca dapat mengambil hikmahnya.Pertama, Pembaca mengidentifikasikan gambaran tentang keberadaan dan ketiadaan Khalifah dan Khilafah.Kedua,Pembaca dapat mengambil nilai-nilai dari peristiwa ini sebagai suatu petunjuk kegigihan perjuangan manusia (Rasulullah) dalam menyampaikan risalah, termasuk juga di sini adalah ajakan/ dakwah.Ketiga, pembaca dapat mengambil nilai-nilai dari peristiwa ini sebagai suatu petunjuk kegigihan perjuangan manusia dalam berdakwah.Pembaca juga dihimbau untuk membentuk kelompok dakwah untuk mewujudkan keberhasilan dakwah Islam.

Kata kunci: Struktur Naratif, Wayang Kekayon Khalifah, Mulabukaning Dakwah Rasul
\end{abstract}

\section{PENDAHULUAN}

Lakon 1 Mulabukaning Dakwah Rasul terdapat pada makro cerita Wayang Kekayon Khalifah. Sebelum diadakan analisis, di bawah ini akan diuraikan tentang hal-hal pokok dalam penelitian naratologi. Teori naratologi menyoroti karya sastra dari tiga segi, yaitu structural (sintaksis), segi makna (semantik) dan segi relasi cerita dengan pencipta dan pembaca (pragmatik).

Naratologi adalah ilmu yang mempelajari karya sastra (bahasa yang berupa cerita atau kisah) naratif. Oleh karena itu naratologi termasuk dalam ilmu linguistic, yaitu lingustik struktural. Analisis dalam naratologi dilakukan seputar apa yang diceritakan dan bagaimana cara cerita itu disampaikan termasuk juga bahasa yang digunakan. Di sini selanjutnya akan dibedakan suatu karya yang berupa sejarah (history) dan karya yang murni (story). Karya yang berupa sejarah digunakan bahasa yang ekspresif, deskriptif sekaligus informatif. Hal ini hanya merupakan suatu peristiwa yang dipaparkan secara apa adanya. Jadi, tidak ada pihak yang memberikan intepretasi (penulis karya). Contoh berita di televisi, radio, dan surat kabar.

Struktur permukaan cerita tampak pada unsur-unsur bahasa material yang berupa ucapan, anak kalimat, kalimat (struktur gramatikal) maupun kesatuan literer yang lebih besar lagi, yaitu adegan dan babak. Unsur-unsur material berhubungan satu sama lainnya membentuk suatu kesatuan literer teratur. Ini akan 
menentukan arti (isi bukan makna) unsur-unsur tersebut. Sehingga gabungan unsur-unsur tersebut akan mendapat arti konkret dari seluruh cerita.

Struktur teks yang kedua adalah struktur mendalam atau mendasar, yaitu keteraturan yang ada di belakang teks material cerita yang ada di tangan.Keteraturan itu tidak menjadi eksplisit dalam teks cerita, meskipun teks itu memang wujud struktur mendalam.Struktur mendalam mengemudikan penulisan dalam meciptakan cerita konkretnya dan mengemudikan pembaca dalam membaca cerita tersebut.Maka, cerita dapat berperan sebagai komunikasi.Jadi, penulis menurut ketentuan tersebut menciptakan atau meng-in-kode ceritanya.Sedangkan pembaca men-de-kode teks cerita dan mengambil pesan dari teks cerita tersebut. Beberapa contoh unsur mendalam adalah sebagai berikut: 1. Paradigmatik dan syntagmatik

Istilah ini merupakan pemadatan dari struktur mendalam dalam rangka system bahasa (langue) tertentu. Paradigmatic adalah proses pemilihan kata-kata yang tepat untuk mengungkapkan sesuatu hal oleh pencipta dengan kosa kata yang tersedia (paradigma). Selain itu, pencipta harus memegang seberkas aturan tentang penggunaaan unsur-unsur bahasa dalam teks konkret seperti sebuah cerita.Dalam menciptakan karya sastra ada dua macam kode yang harus diperhatikan, yaitu kode dalam tingkat kalimat (kode gramatikal) dan kode dalam tingkat karya (kode literer). Kode literer inilah yang akan menentukan jenis karya yang diciptakan. Jadi, penulis cerita meng-inkode teksnya dengan memilih aturan yang tersedia, baik di tingkat kalimat maupun di tingkat karya.Dalam hal ini, Wayang Kekayon Khalifah yang dijadikan penelitian menggunakan aturan-aturan (kode) narasi teks wayang. Sedangkan pembaca men-dekode karya literernya berupa cerita guna mengambil dari pesannya yang akan disampaikan penulis cerita.

2. Struktur mendalam universal

Struktur mendalam universal meliputi semua system bahasa.Hal ini berlaku untuk semua manusia dan semua zaman.Struktur inilah yang memungkinkan diadakan terjemahan dari bahasa yang satu ke dalam bahasa yang lainnya.Struktur mendalam mencakup berbagai unsur abstrak yang harus dikonkretkan berupa cerita. Oleh karena itu struktur itu dapat ditemukan di belakang semua cerita. Unsur-unsur yang termasuk struktur mendalam universal, yaitu:

a. Plot atau erzahlgerust, yaitu unsur yang mengemudikan jalannya cerita, perbuatan, kejadian yang berkaitan satu sama lainnya sebagai sebab dan akibat.

b. Discours atau konfigurasi, yaitu pengisian secara teratur pada kerangka dasar atau plot yang ada pada pencipta cerita.

c. Sequens dan transformasi, yaitu serangkaian tindakan abstrak yang bergerak dari titik tolak (keadaan statis), peralihan (peraturan yang sebenarnya), dan titik akhir (keadaan statis) yang merupakan hasil tindakan.

d. Aktant adalah pemeran abstrak (peranan abstrak) yang mungkin dipentaskan dalam cerita konkret tetapi tidak perlu ditampilkan dalam setiap cerita.

3. Intelligibilitas

Intelligibilitas adalah suatu prinsip structural umum yang ada di belakang teks cerita.Cerita di sini dapat dipahami oleh pembaca, baik dalam keseluruhannya maupun dalam bagian-bagiannya. Sedangkan unsur-unsur yang 
membentuk cerita mesti bersambung satu sama lain dalam urutan tertentu. Semuanya mesti berhubungan dengan plot atau tema cerita dan menjelaskan sebagai sebab akibat atau perincian dan penjelasan. Cerita mesti dapat dipahami antara reaksi cerita dengan dunia orang yang oleh cerita diaktualkan dan relasi dengan dunia orang yang membaca cerita. Akan tetapi kalau tidak ada relasi-relasi tidak dapat dipahami atau bahkan tidak ada, maka tidak akan mempunyai makna bagi pembaca.

4. Tingkat pengetahuan yang berbeda

Tidak semua yang telibat dalam apa yang diceritakan mempunyai tingkat pengetahuan yang sama. Penulis ceritalah yang mempunyai segala pengetahuan di dunia fiktif yang diceritakan.Sebab dialah pencipta dunia itu.Jadi, dia maha tahu. Sedangkan pembaca dapat memahami sejauh yang ia baca dan pahami. Mereka yang dipentaskan dalam cerita tahu hanya apa yang terlibat dan yang diberlakukan kepadanya. Tingkat pengetahuan mereka berbeda.Perbedaan dalam pengetahuan itu dalam cerita menciptakan situasi khusus.

Langkah selanjutnya dalam analisis naratif yaitu analisis semantic. Semantic pada umumnya menanyakan makna yang terkandung dalam tanda-tanda bahasa, yaitu tanda-tanda bahasa yang dapat bermakna. Semantic menanyakan tandatanda bahasa mengacu pada apa yang di luar tanda-tanda bahasa itu, entah realobyektif entah ideal (dan subyektif). Makna yang bertumpu pada arti (relasi atau struktur) cerita maka semantic cerita mengendalikan sintaksis cerita.

Dunia luar yang diacu dan direpresentasikan oleh cerita memang serba majemuk.Akan tetapi semua dapat direduksi menjadi tiga bidang, yaitu ekonomi, sosio-politik, dan ideologis. Dengan tingkat yang berbeda-beda masing-masing bidang direduksikan dalam cerita-cerita konkret yang bisa saja sama persis seluruhnya dengan dunia luar cerita yang diacu oleh cerita. Dunia fiktif cerita selalu merupakan hasil seleksi, interpretasi dan konstruksi.

Langkah ketiga dalam analisis naratif adalah analisis pragmatic.Pragmatik cerita meneliti cerita sebagai salah satu perbuatan (handeln/pragma).Dalam perbuatan ada tiga factor yang berperan, yaitu ada yang melakukan, ada tindakan yang dilakukan dan ada yang menjadi sasaran perbuatan itu.Pragmatic cerita meneliti cerita sebagai perbuatan komunikatif antar manusia.Pargmatik mengandalkan penelitian semantic dan sintaksis. Dalam komunikasi yang memakai bahasa mempunyai beberapa factor yang turut berperan, yaitu pengirim cerita, pembaca/ penerima cerita, pesan yang dikomunikasikan, kode yaitu system bahasa (langue) yang dipahami (paradigmatic dan sintagmatik), jenis sastra yang dipakai. Dan ada saluran yang dipakai (lisan, tertulis, visual dsb).Terakhir adalah konteks, baik konteks social maupun kultural.Komunikasi terjadi apabila pesan cerita dari pihak pengirim memancing reaksi dari pihak pembaca.

\section{HASIL PENELITIAN DAN PEMBAHASAN}

Analisis naratif Lakon Mulabukaning Dakwah Rasul melalui tiga tahapan, yaitu sintaksis, semantic, dan pragmatic akan diuraikan di bawah ini:

Babak I : Deskripsi tentang Khalifah dan Khilafah Sintaksis 
Babak I ini terdiri dari empat jejer (adegan). Yaitu adegan A jejer 1, adegan B jejer 2, adegan 3 jejer 3 dan adegan 4 jejer 4 .

Adegan A. merupakan adegan yang berisi deskripsi tentang Khalifah.Cerita dibuka dengan gambaran pribadi atau sifat-sifat seorang Khalifah.

Jejer 1. Diawali dengan frasa sang khalifah satunggaling Sultan gung binathara 'Khalifah merupakan seorang Sultan yang agung'.Diperkenalkan sifatsifat yang melekat pada seorang Khalifah atau seorang pemimpin.Ada ucapan lokutif yang menerangan tentang sifat-sifat tersebut.

Panjenengane suka paring sandhang marang wong kang kawudan. Paring pangan marang kawulane kang nandhang kaluwen. Paring toya marang sok sintena ingkang nembe kasatan. Paring teken marang wong kang nandhang lelunyon.Paring kudhung marang kawulane kang nembe kepanasan. Paring payung marang kang kodanan. Paring suka marang sedaya kawula ingkang nembe nandhang prihatos.Paring usada mulya dhumateng sedaya ingkang nembe ginanjar sakit. Kejawi punika ugi kagungan raos tresna asih, dhateng mengsah ingkang sampun anungkul.Pramila mboten mokal, lamun panjenenganipun sinuyudan para punggawa dalah kawula dasih.

Sifat seorang Khalifah yang dipaparkan senang memberi sandang kepada rakyatnya yang miskin, memberi makan kepada rakyatnya yang kelaparan, memberi air kepada rakyatnya yang kehausan, memberi tongkat kepada yang sedang berjalan di tempat licin, memberi tutup kepala kepada rakyatnya yang kepanasan, memberi payung bagi yang sedang kehujanan, memberi santunan bagi rakyatnya yang sedang mendapat anugrah berupa sakit. Selain itu, beliau juga memiliki cinta kasih terhadap musuh yang sudah menyerah.Maka dari itu, tidak mengherankan jika beliau dihormati oleh semua pejabat dan rakyatnya.

Jejer 2. Ada ucapan naratif sabdanipun Rasulullah ingkang dipun riwayataken Ahmad bab Khilafah 'sabda Rasulullah yang diriwayatkan Ahmad mengenai Khilafah'. Bahwa Hal ini menjelaskan tentang periodesasi Khilafah.

"Perkawis utusan badhe kedadosan ing satengahing manungsa, kados dene ingkang dipun kersakaken dening Allah. Salajengipun Allah nggantos menawi ngersakaken. Salajengipun badhe wonten Khilafah, ingkang jejeg kanthi cara nubuwah. Lajeng khilafah sawau kados dene ingkang dipun kersakaken Allah.Salajengipun Allah mbusek, menawi ngersakaken mbusek. Salajengipun badhe wonten karaton, ingkang nyepeng Islam kanthi kenceng,lajeng karaton wau kados dene ingkang dipun kersakaken Allah. Lajeng Allah mbusek menawi ngersakaken mbusek. Lajeng wonten karaton degsiya, lajeng karaton wau kados dene ingkang dipun kersakaken Allah. Salajengipun Allah badhe mbusek, menawi ngersakaken mbusek. Salajengipun badhe wonten Khilafah malih, miturut cara nubuwah. Lajeng Rasul mendel..."

Akan datang kepada kalian masa kenabian, dan atas kehendak Allah masa itu akan datang. Kemudian, Allah akan menghapusnya, jika Ia berkehendak menghapusnya. Setelah itu, akan dating masa Kekhilafahan 'ala Minhaaj alNubuwwah; dan atas kehendak Allah masa itu akan datang. Lalu Allah menghapusnya jika Ia berkehendak menghapusnya. Setelah itu, akan dating 
kepada kalian, masa raja yang menggigit (raja yang zalim), dan atas kehendak Allah masa itu akan datang. Lalu, Allah menghapusnya, jika Ia berkehendak menghapusnya. Setelah itu, akan dating masa raja dictator (pemaksa); dan atas kehendak Allah masa itu aka ndatang; lalu Allah akan menghapusnya jika berkehendak menghapusnya. Kemudian, datanglah masa Khilafah 'ala Minhaaj al-Nubuwwah (Khilafah yang berjalan di atas kenabian). Setelah itu, beliau diam.....".

Jejer 3.Ada ucapan lokutif yang menjelasakan kisah selanjutnya yaitu gambaran Negara Khilafah gegambaran negari Khilafah. Bahwa Negara Khilafah menggunakan tata cara Islam. Ingkang mandhegani inggih menika sawijining Khalifah.

Satunggaling negari, ingkang tata cara panggulawentah saben dintenipun ngangge tata cara Islam. Inggih menika negari ingkang dipunjejegaken, dening Rasulullah SAW ing Madinah kanthi tata-cara nubuwah. Sasedanipun Rasulullah dipunlajengaken kanthi tata cara Khilafah. Negari Khilafah nggadhahi gendera, kados dene ingkang sampun dipun agem dening Rasulullah SAW. Al-liwa lan ar-rayah inggih menika genderanipun. Miturut basa nggadhahi teges al-'alamu (gendera). Wonten ing kamus alMuhith dipun sebataken rawiya, ar-Rayah sami kaliyan al- 'alamu tegesipun gendera. Wondene panganggenipun liwa-royah miturut syara' inggih menika, Al-liwa warni pethak kanthi seratan laa ilaaha illa Allah Muhammad Rasulullah, warni cemen. Gendera menika dipun cepeng dening tetungguling prajurit. Ugi minangka tandha, papan dununging tetungguling prajurit wau. Ar-Rayah warni cemeng, kanthi seratan laa ilaaha illa Allah Muhammad Rasulullah warni pethak. Ar-Rayah dipun cepeng sesarengan kaliyan tetungguling prajurit sanesipun. Paugeraning peprentahan inggih menika kanthi cara Khilafah, sanes karaton, sanes kakaisaran, sanes republic, sanes ugi federasi, napa malih teokrasi lan demokrasi. Wujuding Negari lan sipatipun paprentahan inggih menika nyawiji, sanes federasi/ menapa dene persemakmuran. Minangka pathokaning ukum inggih menika Al-Quran, As-Sunnah, Ijma'sahabat, lan ugi qiyas syar'ie. Wondene pondhasi paugeraning tata caranipun, punjering kedaulatan wonten regemaning Allah. Dene panguwasa ingkang hak milih, inggih menika ingkang dipun rengkuh yaiku umat. Umat piyambak ingkang wajib milih, kanthi pangajab, Khalifah ingkang kapilih saged ngetrapaken ukum syara', kagem paugeraning negari. Tata-cara ing salebeting negari, ngatur ruwet rentenging negari, lan rakyat kanthi syariat Islam ingkang kaaffah. Tata-cara ing njaban rangkah, ngganda arumaken Islam saindenging bawana kanthi dakwah lan jihad. Basa resmi negari, sami kaliyan basa ing kitab suci Al-Quran, inggih menika basa Arab. Ingkang dados warganipun inggih menika muslim lan non muslim ahlu dzimmah. Wewengkonipun boten wonten wates ingkang gumathok, ananging saya wiyar-saya wiyar, jumbuh kaliyan dakwah ingkang dipuntindakaken. Wondene etangan tanggalan temtu kemawon ngangge hijriah. Kangge dol tinuku ngagem dinar (emas) lan dirham (perak). 
Yang memimpin adalah seorang khalifah.Negara khilfah yang dicontohkan/ yang didirikan oleh Rasulullah di Madinah dengan tata-cara nubuwah.Sepeninggal rasul dilanjutkan dengan system khilafah.Negara khilafah menggunakan bendera liwa' dan royah.System pemerintahannya dengan system khilafah, bukan kerajaan, republic, federasi, teokrasi dan demokrasi.Yang menjadi dasar hokum adalah Al-Quran, As Sunah, ijma' sahabat dan qiyas syar'i. Penguasa atau khalifah yang berhak memilih adalah rakyat yang akan dipimpinnya. Khalifah yang dipilih menerapkan hokum syara'. Tata cara di dalam Negara menerapkan syariat islam yang sempurna. Tata cara di luar negari mengharumkan islam dengan dakwa dan jihad. Bahasa resmi sama dengan yang ada di kitab suci, yaitu bahasa Arab. Yang menjadi warganya adalah muslim dan non muslim ahlu dzimmah. Batas wilayah fleksibel, semakin luas seiring dakwah yang dilakukan.Hitungan kalender dengan hijriah.Mata uangnya dengan dinar dan dirham.

Jejer 4. Dikisahkan selanjutnya, Kocap kacarita.Bocah-bocah jaman saiki, lair ing tahun 1950an M,lan dumugi sakmenika,Khilafah dereng madeg malih.Dereng nate ningali Daulah Islam ingkang nindakaken tata cara Islam.

Diceritakan generasi yang lahir tahun 1950an M tidak mendapatkan gambaran Khilafah yang menjalankan tata-cara system kehidupan dengan Islam.Hal ini berbeda dengan generasi di akhir daulah Khilafah Utsmaniyah, meskipun sudah terkoyak.

Benten kaliyan tetiyang ingkang gesang ing pungkasaning jaman daulah Islam, inggih daulah Utsmaniyah. Ingkang dipun busek dening bangsa Landa tahun 1924 M. Dheweke kabeh inggih menika satunggaling tetiyang, ingkang taksih menangi brongkalan-brongkalan, cuwil-cuwilan, remukremukan daulah, lan tinggalane daulah Islam.

Ada penjelasan selanjutnya tentang generasi tahun 1950an M ini sampai sekarang (Khilafah belum terwujud lagi) yang kesulitan menggambarkan wujud Khilafah. Kesulitan tersebut karena tsaqafah Barat yang menjelaskan Khilafah dengan cara mereka. Sebagai pembuka kisah dan penjelas isi cerita, bahwa Wayang Kekayon Khalifah tidak menceritakan tentang daulah Islam tetapi menceritakan bagaimana Rasulullah mendirikan daulah Islam dengan nubuwwah.Selain itu juga menceritakan tentang orang-orang kafir memberangus daulah Islam. Yang terakhir adalah menceritakan bagaimana cara umat Islam mendirikan daulah Islam kembali sehingga menjadi rahmat bagi alam. Hal ini bisa dilihat penjelasan berikut;

minangka bebuka, sejatosipun wayang Kekayon Khalifah menika, boten badhe nyujarahaken daulah Islam. Wayang Khalifah nggadhahi ancas, sepisan ngambaraken dhateng bebrayan ageng ngengingi pripun anggenipunRasulullah SAW ngedegaken Daulah Islam ing Madinah. Kaping kalih pripun tiyang kafir mbusek Daulah Islam.Kaping tiga pripun 
caranipun umat Islam ngedegaken Daulah Islam malih, satemahndadosaken rahmat tumrap sedaya alam.

Berdasarkan analisis sintaksis pada babak I terdapat adanya struktur kisah sabagai berikut: penulis (adresant) mengirimkan pesan keberadaan, ketiadaan dan akan adanya lagi Khilafah kepada adresat (pembaca).

Semantik

Seperti sudah dipaparkan di muka tentang hal ini bahwa semantic merupakan realitas yang bagaimana diacu oleh cerita.Bila dibaca secara seksama maka ada cerita realistis-fantastis, yaitu Ketiadaan Khilafah.

Pada adegan Akerealistisannya bisa diketahui, yaitu gambaran seorang pemimpin atau Khalifah yang memimpin dengan adil.

Pada adegan B bisa diketahui, berkenaan dengan sabda Rasulullah tentang kepemimpinan/ Khalifah ataupun keberadaan Khilafah.

Pada adegan $\mathrm{C}$ hal yang fantastis terlihat pada kisah gambaran tentangKhilafah.

Hal fantastis pada adegan D babak I ini dapat dilihat pada gambaran ketiadaan dunia tanpa Khilafah.

Pragmatik

Seperti sudah dijelaskan pragmatic menyatakan reaksi antar cerita (teks) antara pencipta dengan pembaca.Dengan demikian, analisis pragmatic mengacu penulis (real maupun implied author) sebagai pengirim cerita dan pembaca (real maupun implied reader) sebagai penerima berita.

Penulis: penulis ingin menunjukkan gambaran tentang Khalifah dan Khilafah.

Pembaca:

Pembaca mengidentifikasikan gambaran tentang keberadaan dan ketiadaan Khalifah dan Khilafah.

Babak II: Permulaan Dakwah Rasul

Babak ini terdiri dari 5 jejer.Sedangkan pembagian adegannya penulis bagi menjadi 5 bagian, yaitu adegan A sampai D. Adegan A Jejer 1, B jejer 2, C jejer 3, D jejer 4 dan E jejer 5 .

Adegan A terdapat padajejer 1, merupakan situasi awal babak 2 permulaan dakwah rasul.Rasulullah mengajak istriya, yaitu Khadijah masuk agama Islam.

Rikala Rasulullah saw dipun utus, piyambakipun ngajak garwanipun inggih punika Khadijah ngrungkebi agami Islam, lajeng piyambakipun pitados.

Adegan B terdapat pada Jejer 2.Ditandai dengan frase saksampunipun menika wahyu pedhot 'setelah ini wahyu putus' memberikan penjelasan bahwa ini menandai kisah baru. Dikisahkan bahwa Rasulullah sedih, kemudian malaikat Jibril datang membawa surat Ad-Dhuha. Ada ucapan lokutif yang menjelaskan tersebut, yaitu lajeng malaikat Jibril rawuh kanthi ngasta surat Ad-Dhuha. 
Adegan C terdapat pada jejer 3.Melanjutkan kisah selanjutnya, yaitu kewajiban melaksanakan sholat.Namun demikian Rasulullah terlebih dahulu diajari bagaimana wudhu dan sholat serta waktu-waktu mengerjakan sholat.

Nalika ingkang sepisanan sholat dipun wajibaken dhateng Rasulullah saw. Malaikat Jibril rawuh dhateng Rasul. Ing nalika iku Rasul saw wonten ing gunung Makkah. Malaikat Jibril paring tandha dhateng Rasulullah,kanthi tungkakipun ing lembah, lajeng lembah kasebut medal toya inggih tuk. Lajeng malaikat Jibril wudhu-rasul ningali-kanthi pangajab, paring warah dhateng rasul tata cara wudhu kagem sholat. Lajeng Rasul wudhu kados dene malaikat Jibril wudhu. Lajeng malaikat Jibril jumeneng lan sholat. Rasul nindhakaken sholat, kados dene malaikat Jibril. Sak sampunipun punika, malaikat Jibril ninggalke Rasul.'Wiwitanipun sholat dipun wajibaken dhateng rasulullah'.

Setelah itu Rasulullah mengajarkan wudhu dan sholat kepada Khadijah, istrinya.

Salajengipun Rasul saw manggihi Khatijah. Lan wudhu, kangge ngetingalaken dhateng Khadijah cara sesuci kagem sholat, kados dene ingkang dipun ketingalaken malaikat Jibril dhateng piyambakipun.

Khadijah lajeng wudhu kados dene Rasul saw wudhu kagem piyambakipun. Salajengipun Rasul saw sholat kados dene malaikat Jibril sholat kaliyan piyambakipun. Lan Khadijah sholat kados dene piyambakipun sholat.

Malaikat mengajari waktu-waktu mengerjakan sholat.

He Muhammad, wektu sholat yaiku tengah-tengah saka sholatmu dina iki lan sholatmu wingi.

Adegan D terdapat pada jejer 4.Merupakanadegan baru dengan situasi kejadian yang berbeda dari sebelumnya.Ali bin Abi Thalib masuk agama Islam.

Tiyang kakung ingkang sepisanan pitados dhateng Rasul saw, sholat bareng lan ngleresaken ingkang panjenenganipun beta inggih menika Ali bin Abu Thalib bin Abdul Muththalib bin Hasyim.

Adegan E terdapat pada jejer 5.Ditandai dengan ucapan naratif yang melanjutkan kisah berikutnya.Zaid bin Haritsah di dalam agama Islam.

Kocap kacarita/ Rasulullah saw ngajak maula/ inggih budak/ utawi rewangipun/inggih menika Zaid/piyambakipun lajeng pitados.

Semantic

Babak II mempunyai realitas fantastis karena menampilkan sebuah kisah yang sangat luar biasa. Pada adegan A menampilkan sebuah realitas seorang saudagar kaya raya masuk agama Islam. Ini dilakukan untuk menyokong dakwah rasulullah.Maka kisah pada adegan ini dapat diletakkan dalam kerangka fantastis/ luar biasa. 
Pada adegan B bisa diketahui, Rasulullah sebagai seorang rasul tetapi wahyu tersebut putus. Ini terjadi karena sayangnya Allah kemudian turunlah surat AdDhuha yang memberikan kabar gembira tersebut.

Pada adegan $\mathrm{C}$, hal ini yang fantastis dapat diketahui saat rasul diperintahkan untuk melaksanakan sholat yang pertama kali dengan dua rakaat.Hal ini berbeda dengan nabi-nabi sebelumnya.

Pada adegan D. hal yang fantastis adalah bahwa Ali putra Abu Thalib yang saat itu masih kecil sebelum turun wahyu pertama kali. Ali bin Abu Thalib merupakan orang lelaki pertama kali yang masuk Islam.

Pada adegan E. hal fantastic adalah Zaid bin Haritsah, seorang budak yang masuk Islam kedua setelah Ali bin Abi Thalib.

Pragmatic

Penulis: inisiasi yang disampaikan melalui tokoh utama Rasulullah mengajak keluarga dekatnya untuk masuk Islam dan melakukan dakwah bersama Rasulullah. Ajakan Rasulullah berhasil dan siap untuk mengajak orang-orang di luar anggota keluarganya (para sahabatnya).Hal tersebut dapat diketahui pada babak berikutnya yaitu dakwah rasul wiwit kanthi terwaca.

Pembaca:

Pembaca dapat mengambil nilai-nilai dari peristiwa ini sebagai suatu petunjuk kegigihan perjuangan manusia (Rasulullah) dalam menyampaikan risalah, termasuk juga di sini adalah ajakan/ dakwah.

Babak III: Dakwah Rasul Mulai dengan Terang-Terangan

Babak ini terdiri dari 5 jejer.Sedangkan pembagian adegannya penulis bagi menjadi 5 bagian, yaitu adegan A sampai D. Adegan A Jejer 1, B jejer 2, C jejer 3, D jejer 4 dan E jejer 5 .

Adegan A terdapat padajejer 1, merupakan situasi awal babak 3 dakwah rasul mulai terang-terangan.Rasulullah mengajak sahabat karibnya, yaitu Abu Bakar masuk agama Islam.

Rasulullah ngajak kanca kenthelipun inggih menika Abu Bakar, piyambakipun boten tidha-tidha malih lajeng pitados.

Setelah Abu Bakar masuk agama Islam, maka semakin banyak orang-orang Arab yang masuk agama Islam melalui Abu Bakar.

Pramila boten mokal menawi Utsman Bin Affan, Zubair bin Awwam, Abdurahman bin Auf, Sa'ad bin Abi Waqash, lan Thalhah bin Ubaidillah ngrungkepi Islam lantaran piyambakipun. Abu Bakar sowan Rasul sesarengan, kabeh mlebet Islam lan nindakaken sholat.

Adegan B terdapat pada Jejer 2.Ditandai dengan ungkapan narasi yang menunjukkan Rasulullah membentuk kelompok dakwah yang berjumlah empat puluh orang.

Pungkasanipun piyambakipun sasarengan damel kelompok ingkang siap nindakaken dakwah. Gunggung tetiyang wiwit dipun utusipun Rasulullah ngantos wonten prentah ngetingalaken dakwah kanthi terwaca utawi thok leh wonten kawan dasa tiyang. 
Adegan C terdapat pada jejer 3.Melanjutkan kisah selanjutnya, yaitu orang-orang Makkah mengetahui bahwa banyak yang masuk agama Islam dan bersama Rasulullah.

Kocap kacarita dakwah Islam ketingal wiwit dipun utusipun Rasulullah saw. Nalika iku bebrayan ageng Makkah mangertosi bilih Muhammad saw ngajak dhateng agama ingkang enggal. Tiyang-tiyang Makkah mangertosi/ bilih kathah tetiyang ingkang mlebet agami Islam/ sesarengan kaliyan Rasulullah saw.

Kejadian ini menimbulkan ketidak senangan orang-orang Makkah sehingga aktifitas sholatnya Rasulullah dan para sahabat mendapatkan perhatian. Sampai suatu saat terjadi tumpahnya darah yang pertama dalam dakwah Islam oleh Saad bin Abu Waqqash.

Saad bin Abu Waqqash ngepruk salah sawijining tetiyang musrikin ngangge balung onta ngantos godres getih. Inggih getih menika minangka ingkang sepisanan wutah ing dakwah Islam.

Adegan D terdapat pada jejer 4.Merupakanadegan baru dengan situasi dan lokasi kejadian yang berbeda dari sebelumnya.Rasulullah tetap gigih memegang agama Islam meskipun orang-orang musrik menghalang-halanginya. Kegigihan Rasulullah dibuktikan dengan ungkapan yang disampaikan ke Abu Thalib, yaitu seandainya mereka meletakkan matahari di tangann kananku dan bulan di tangan kiriku agar aku meninggalkan persoalan ini hingga Allah memenangkan perkara ini atau aku mati karenanya, niscaya aku tidak meninggalkan persoalan ini.

Rasulullah lajeng nyabda, Paklik, namung kagem Allah swt; saumpami tetiyang kafir Quraisy ndelehake srengenge ing tangan tengenku lan mbulan ing tangan kiwaku supaya aku ninggalke perkara iki dumugi Allah paring menang perkara iki apa aku kudu mati. Kamangka aku ora bakal ninggalke perkara iki.

Adegan E terdapat pada jejer 5.Ditandai dengan frase kahanan saya panas. Situasi di Makah semakin panas, hanya saja yang menarik adalah Abu Thalib tetap melindungi Rasulullah.

Salejengipun tetiyang Quraisy ngancam para kabilah menawa ing salebetipun kabilah wau wonten sakabat Rasulullah saw ingkang mlebet Islam. Saben kabilah padha nyekel tetiyang Islam ing satengahing kabilah wau lajeng tumindak aniaya amargi lumebet agami Islam.Rasulullah saw dipun rengkuh Allah swt sarana Abu Thalib.

Selain itu Abu Thalib mengajak orang-orang tetap bersamanya dengan membuat puisi.

Abu Thalib damel cakepan gurit ingkang nedhaken bombongipun dhateng tetiyang ingkang tumut mbela piyambakipun.

Hal ini dilakukan untuk memperkuat dukungan mereka padanya. 
Abu Thalib nindakaken mekaten supados tetiyang wau saya manteb sareng piyambakipun nyengkuyung Rasulullah saw. Semantik

Babak III mempunyai realitas fantastis karena menampilkan sebuah kisah yang sangat luar biasa. Pada adegan A menampilkan sebuah realitas seorang saudagar kaya raya (Abu Bakar) masuk agama Islam. Hal tersebut dikarenakan Abu Bakar sangat percaya kepada Rasulullah yang terdidik oleh Al-Quran, baik dari sisi tutur kata maupun perbuatan.Rasulullah satu-satunya orang yang paling dipercaya oleh Abu Bakar.Maka kisah pada adegan ini dapat diletakkan dalam kerangka fantastis.

Pada adegan B bisa diketahui, Rasulullah meskipun sebagai seorang rasul tetapi metode dakwah tetap mengetengahkan kemanusiaannya.Rasulullah membentuk kutlah dakwah yang nantinya untuk dakwah yang lebih luas lagi.

Pada adegan $\mathrm{C}$, hal ini yang fantastis dapat diketahui saat sahabat rasul melakukan sholat di Syi'ib.Kemudian datang para kafir Qurais menghina para sahabat. Dengan serta merta Saad bin Abu Waqash memukul penghina tadi dengan tulang onta sampai berdarah-darah. Kejadian ini menjadi tumpahnya darah yang pertama kali dalam dakwah Islam.

Pada adegan D. hal yang fantastis adalah bahwa Rasulullah tetap kokoh memegang agama Islam. Ada hal yang fantastis ketika Rasulullah mengatakan bahwa sekiranya orang-orang kafir Qurais meletakkan matahari di atas tangan kanannya dan bulan di tangan kirinya, supaya Rasulullah meninggalkan perkaranya sampai Allah memenangkan perkaranya atau Rasulullah mati karenanya maka Rasulullah tidak akan meninggalkan perkaranya.

Pada adegan E. hal fantastic adalah ketika Abu Thalib melindungi Rasulullah di saat Abu Lahab membencinya.

Pragmatic

Penulis: inisiasi yang disampaikan melalui tokoh utama Rasulullah mengajak para sahabat untuk masuk Islam dan melakukan dakwah bersama Rasulullah. Ajakan Rasulullah berhasil dan membentuk kelompok dakwah yang siap untuk melakukan dakwah menyeru kapada Islam.

Pembaca:

Pembaca dapat mengambil nilai-nilai dari peristiwa ini sebagai suatu petunjuk kegigihan perjuangan manusia dalam berdakwah.Pembaca juga dihimbau untuk membentuk kelompok dakwah untuk mewujudkan keberhasilan dakwah Islam.

\section{PENUTUP}

Lakon Mulabukaning Dakwah Rasul dalam Wayang Kekayon Khalifah terdiri dari tiga babak. Di antara babak yang satu dengan babak yang lainnya tidak memiliki bagian yang sama. Sebagian besar berupa narasi dan dialog sehingga membentuk adegan. Dapat diketahui bahwa tiap babak dalam lakon Mulabukaning dakwah Rasul memiliki ikatan dan jalinan yang berkelanjutan.Artinya, satu babak berkaitan dengan babak lainnya. 
Ada tiga hal yang dapat diambil pembaca dari kisah itu.Pertama, pembaca mengetahui gambaran tentang keberadaan dan ketiadaan Khalifah dan Khilafah.Kedua, pembaca dapat mengambil nilai-nilai dari peristiwa ini sebagai suatu petunjuk kegigihan perjuangan manusia (Rasulullah) dalam menyampaikan risalah.Ketiga,pembaca dihimbau untuk membentuk kelompok dakwah untuk mewujudkan keberhasilan dakwah Islam.

\section{DAFTAR PUSTAKA}

Abdul Malik bin Hisyam Al-Muafiri, Abu Muhammad. 2005. Sirah Nabawiyah Ibnu Hisyam. Jakarta. Darul Falah.

Adnan, Muhammad. 1985. Tafsir Al-Quran Suci Basa Jawi. Bandung. P.T AlMa'arif.

An-Nabhani, Taqiyuddin. 1994. Negara Islam; Tinjauan Faktual Upaya Rasulullah SAW membangun Daulah Islamiyah Hingga Masa Keruntuhannya. Bogor. Pustaka Thariqul 'Izzah.

Balai Bahasa Yogyakarta. 2006. Pedoman Umum Ejaan Bahasa Jawa Huruf Latin yang disempurnakan. Yogyakarta. Kanisius.

Caritagama, Ki Lutfi. 2015. Seri Wayang Kekayon Khalifah Lakon 1 Mulabukaning Dakwah Rasul. Yogyakarta.Attuqo.

Gericke, JFC dan T. Roorda. 1901. Javaansch-nederlandsch handwoordenboek dell I. Leiden. Boekhandel en Drukkerij Voorden E.J Brill.

Gericke, JFC dan T. Roorda. 1901. Javaansch-nederlandsch handwoordenboek dell II. Leiden. Boekhandel en Drukkerij Voorden E.J Brill.

Groenen, C., 1993. Analisis Naratif Kisah Sengsara (Yoh 18-19). Yogyakarta: Kanisius.

Machali, Rochayah, 2000. Pedoman Bagi Penerjemah. Jakarta: Grafindo

Poerwadarminta, W.J.S. 1939. Baoesastra Djawa. Batavia: J.B. Walters Uitgevers.

Prabowo, Dhanu priyo. 2007. Glosarium Istilah Sastra Jawa. Yogyakarta.Narasi.

Diktat Kumpulan Sekar Alit Sekar Tengahan Sekar Ageng lan Lagon-Lagon Siswa Sekar Kawedanan Hageng Krodomardawa Kraton Ngayogyakarta Hadiningrat 